University of Rhode Island

DigitalCommons@URI

The Rhode Island Current Conditions Index

Economics

$12-2018$

\title{
Rhode Island Current Conditions Index - December 2018
}

Leonard Lardaro

University of Rhode Island, lardaro@uri.edu

Follow this and additional works at: https://digitalcommons.uri.edu/ricci

Part of the Econometrics Commons

Terms of Use

All rights reserved under copyright.

\section{Recommended Citation}

Lardaro, Leonard, "Rhode Island Current Conditions Index -- December 2018" (2018). The Rhode Island Current Conditions Index. Paper 180.

https://digitalcommons.uri.edu/ricci/180

This Newsletter is brought to you for free and open access by the Economics at DigitalCommons@URI. It has been accepted for inclusion in The Rhode Island Current Conditions Index by an authorized administrator of DigitalCommons@URI.For more information, please contact digitalcommons-group@uri.edu. 


\title{
CURRENT CONDITIONS
INDEX
}

\section{LEONARD LARDARO, URI}

\author{
Available Online: http: / www.Ilardaro.com/current.htm \\ Twitter: @ladardo
}

VOL XXVI

NUMBER 1

DEC 2018

Rhode Island closed out 2018 on a rather downbeat note. After beginning the year with fairly strong economic performances during several months, things noticeably deteriorated in the second half. Negatives changes increasingly emerged, gaining significance relative to positive factors, causing the magnitudes of changes in various indicators to slip quite a bit. Most notably, during one month, the Current Conditions Index registered a contraction value (42 in October). Even with an upgrade to November's value (from 58 to 67 based on Single-Unit Permits), the CCI only managed to exceed year-earlier values for two months throughout all of 2018. The CCI ended the year with a neutral value of 50 , a decrease from November yet another confirmation of a decelerating Rhode Island's economy.

Evidence of a slowing Rhode Island economy is becoming increasingly abundant. Our state's Labor Force reached its most recent peak in August, along with labor force participation rate, the percentage of the working-age population in the Labor Force. Both have trended downward on a monthly basis since that time, indicating that a number of the second-half improvements in our state's Unemployment Rate occurred for the wrong reasons. Related to this is the behavior of our employment rate, the percentage of our working-age population that is employed. That rate had been stuck at 62.3 percent since

\section{Indicators - \% Change}

\begin{tabular}{|l|r|r|}
\hline Government Employment & -0.2 & \\
\hline US Consumer Sentiment & 2.6 & $\mathrm{Y}$ \\
\hline Single-Unit Permits & -4.9 & \\
\hline Retail Sales & 10.8 & $\mathrm{Y}$ \\
\hline Employment Services Jobs & 1.7 & $\mathrm{Y}$ \\
\hline Priv. Serv-Prod Employment & 2.0 & $\mathrm{Y}$ \\
\hline Total Manufacturing Hours & -4.3 & \\
\hline Manufacturing Wage & -1.5 & \\
\hline Labor Force & 0.9 & $\mathrm{Y}$ \\
\hline Benefit Exhaustions & 14.7 & \\
\hline New Claims & 11.3 & \\
\hline Unemployment Rate (change) & -0.6 & $\mathrm{Y}$ \\
\hline \multicolumn{2}{|c|}{ Y = Improved Value } \\
\hline
\end{tabular}

August, then slipped to 62.2 percent in December, remaining well $(5 \%)$ below its prior cyclical peak of 65.4 percent all the way back in January of 2007! One of the most disturbing trends concerns New Claims, the timeliest measure of layoffs. These have now risen for four of the most recent six months, reflecting the likelihood that a trend of rising layoffs may well be occurring. Total Manufacturing Hours, a proxy for manufacturing output, has now declined for the most recent three months. The Manufacturing Wage has fallen for the most recent four months. The list of disappointments goes on and on.

Unless labor market data rebenchmarking reverses many of these disturbing changes, the debate concerning whether Rhode Island is moving ever closer to a recession cannot be dismissed. Since we are FILO, and the national and global economies are slowing, continually monitoring our state's economic condition has become more important than it has been in a long time.

For December, only six of the twelve CCI indicators improved. Individual indicator performances were generally weaker than November, and only two of the five leading indicators contained in the CCI improved. Since the recent May high, the CCI has not gone straight down. But having two of the three fourth-quarter CCI values either in the contraction or neutral range is a cause for concern.

New Claims, as stated earlier, performed badly in December, rising at a double-digit rate $(+11.3 \%)$, its fourth increase in the last six months. Rhode Island's goods-producing sector's performance was very disappointing yet again in December. Total Manufacturing Hours, which reflects manufacturing output, fell for the third consecutive month $(-4.3 \%)$. Along with this, the Manufacturing Wage declined again $(-1.5 \%)$. SingleUnit Permits, which reflect new home construction, fell for the sixth time in the last seventh months $(-4.9 \%)$ (my estimate since data is still unavailable due to the government shutdown). Employment Service Jobs, a leading labor market indicator that includes temporary employment, improved again $(+1.7 \%)$ but at a slower rate than November. US Consumer Sentiment rose in December $(-2.6 \%)$ for the first time in three months.

As noted earlier, both of the "left behind" indicators, the employment rate and the labor force participation rate, failed to improve again in December. Both remain well below their prior cyclical highs (see table). It is quite possible that neither will surpass their prior highs during this entire cycle.

Retail Sales grew very strongly again in December $(+10.8 \%)$ Government Employment fell from its level a year ago for a fourth consecutive month $(-0.2 \%)$, Private Service-Producing Employment growth rose by 2 percent, and Benefit Exhaustions, the timeliest measure of longer-term unemployment, rose sharply in December $(+14.7 \%)$. The Unemployment Rate remained below 4 percent, driven largely by a Labor Force that fell for the third consecutive time on a monthly basis.

$\begin{array}{rrr}\text { LABOR FORCE; } & \text { Dec 2018 } & \text { Peak (1/2007) } \\ \text { Participation Rate } & 64.7 \% & 68.6 \% \\ \text { Employment Rate } & 62.2 \% & 65.4 \%\end{array}$

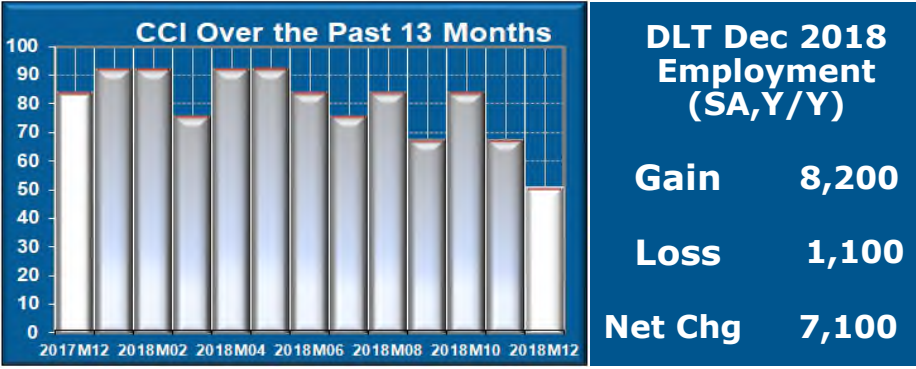

\begin{tabular}{|l|l|l|l|l|l|l|l|l|l|l|l|l|l|}
\hline & Jan & Feb & Mar & Apr & May & Jun & Jul & Aug & Sep & Oct & Nov & Dec \\
\hline 2017 & $75 \uparrow$ & $83 \uparrow$ & $92 \uparrow$ & $75 \uparrow$ & $83 \uparrow$ & $92 \uparrow$ & $75 \uparrow$ & $92 \uparrow$ & $92 \uparrow$ & $92 \uparrow$ & $92 \uparrow$ & $83 \uparrow$ \\
\cline { 2 - 12 } & 2018 & 75 & 92 & 75 & $75 \uparrow$ & 92 & 83 & 75 & $83 \uparrow$ & 67 & 42 & $67 \uparrow$ & 50 \\
\hline
\end{tabular}

Copyright ( 2017,2018 Leonard Lardaro, Ph.D. All rights reserved. 